\title{
Thinking and Being: From Parmenides to Descartes and Beyond
}

\author{
Eleni Papamichael ${ }^{1^{*}}$ \\ ${ }^{1}$ Cyprus Research Centre, Ministry of Education and Culture, Nicosia, Cyprus \\ *Eleni Papamichael, E-mail: e.papamichael@yahoo.com
}

Received: May 30, 2017 Accepted: October 5, 2017 Online Published: November 22, 2017

doi:10.22158/wjssr.v4n4p356 URL: http://dx.doi.org/10.22158/wjssr.v4n4p356

\begin{abstract}
This paper concentrates on the effort to trace the limits of the "revolution" which the Cartesian "Cogito" brought about in the history of Philosophy, within the context of a broader research that begins with Parmenides' Poem. The research in question concerns the general issue of the correlation between thinking (voeiv) and being (Eĩval) to which the "Cogito" itself, as such, refers one. Despite the apparent agreement of Parmenides and Descartes on this issue, what this paper aims first of all, is to demonstrate the radical difference which in reality exists, regarding this issue, between these two philosophers, as well as, more generally, between Descartes and the ancient Greek spirit. From the abandonment of this spirit, essentially springs forth the concept of the individual consciousness, which, in the future, was to form the basis for the creation of certain new philosophical theories, whose sole common element would be the reference to this concept. After Descartes, and all the way towards Structuralism, there have, however, also been developed certain theories of another type, which have

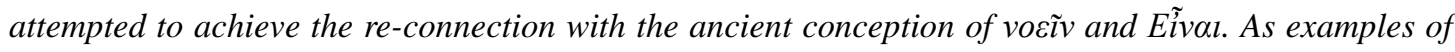
this effort, this paper denotes the theories of Kant, Hegel and Heidegger.
\end{abstract}

\section{Keywords}

voeiv, \&ĩval, thought, existence, Parmenides, Descartes, cogito

\section{Introduction}

The severe criticism exercised by Kant against the Cartesian proposal "Cogito ergo sum" (Note 1) is well known. In his criticism, Kant holds that this proposal, which forms the sole basis for an entire science, is in fact founded on "absurdities" (Note 2).

The "Cogito" is nonetheless a milestone in the history of Philosophy, and Descartes himself is indisputably the acknowledged father of Modem European Philosophy. What would, therefore, be interesting would be to attempt to define the limits of the "revolution" which the "Cogito" has brought about in the field of Philosophy, and to define those limits within a broader study of the actual subject matter of the relation between thought and existence, to which the "Cogito" itself, as such, refers one. 


\section{Method of Analysis}

Before embarking on such an attempt, it is necessary first to stress that the limits of the revolutionary importance of the "Cogito" to Philosophy can only be determined if the "Cogito" is examined in comparison to that philosophical view of the world which is not the one that immediately preceded it. To compare it with Medieval Philosophy would be tactically incorrect, given that opposition to the dogmatic philosophy of the scholastic philosophers and the radical laying of new foundations, rationalistic foundations, to the edifice of science and Philosophy, is the declared purpose of Descartes' entire work (Note 3). Any comparisons should be made with even earlier times, specifically in the very origins of the history of Philosophy itself, since the meaning of the phrase "Cogito, ergo sum”, which lies in the eternally indivisible relation between thought and existence, between vocĩv and Eĩval, was certainly not first conceived of by Descartes. It had already been both conceived and expressed by the

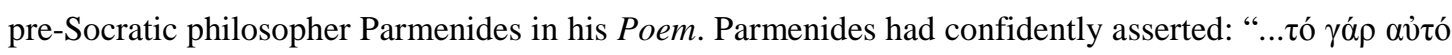

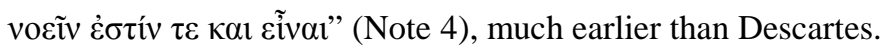

\section{Main Content}

\subsection{The Cartesian "Cogito" and Parmenides' Poem Fragment III}

Of course, Parmenides' meaning is much more general than that of Descartes: it does not confine itself merely to an awareness of the individual consciousness. It does not refer specifically to the subject, but to existence in general, to Being. For Parmenides, only thought, or rather intellection, is capable of grasping Being, the true reality of beings. Anything sensed or perceived by the senses is to him neither true nor, by extension, actual or real, but merely a false impression. (Note 5) Consequently, since Being can be conceived only by thought or intellect, Being is the natural, exclusive, and only possible object of thought.

The truth of this Parmenidean perception of Being as the exclusive object of thought, and in consequence, the truth of this clear distinction between the two-between Being on the one hand and thought on the other-in no way confutes Parmenides' parallel view of the existence of an inter-dependent relation between thought and Being. Indeed, the relation is such that thought and Being

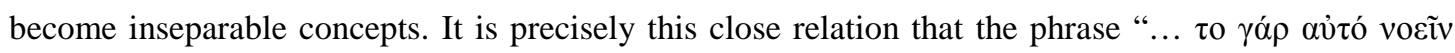

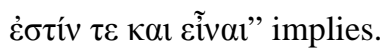

Of course, in order to compare Parmenides' Poem Fragment III with the Cartesian "Cogito", it is necessary at this point to raise the question of what is the true interpretation of this particular fragment.

Any superficial approach to an interpretation of this fragment could result in nothing more than the conclusion that thought and Being are identical. Such a conclusion, however, does not convey the true meaning of what Parmenides is saying. Indeed, how could thought and existence, thought and Being, be considered identical by Parmenides, since for the pre-Socratic philosopher Being is not merely the object, but as mentioned earlier, the only natural and possible object of thought-while anything other 
than what is mentally conceivable considered as non-existent and merely an illusion?

Indeed, for Parmenides, Being is conceivable only through thought; and since only Being, or rather the

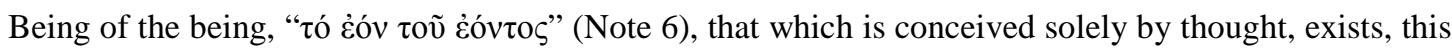
automatically also becomes the exclusive object of thought, with which, in consequence, thought itself cannot be equated. Of course, the question remains regarding the use of the word “ $\alpha$ tó”. Why does Parmenides choose this particular word? In our view, Parmenides chooses it because he wishes to emphasize the idea of inter-dependence and indivisible co-existence, and not with a view to indicating that the two can be truly equated.

In other words, what Parmenides is trying to say, is that, since what exists is only the "๕́cóv", and in consequence, not an alternation between being and non-being-to the possibility of which any subjective opinion could conclude_-and since "غ̇óv" can be conceived only by thought, thought which conceives the "ćóv" is itself within the "ćó $v$ ”; necessarily exists. It exists and its existence automatically means the existence of its content. And the content of thought - that is to say, anything real which exists and may be conceived by thought in thought—is precisely the content of the "غ̇óv"

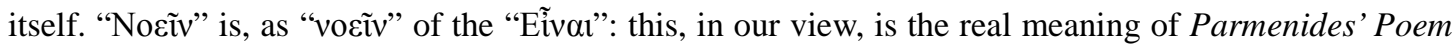
Fragment III. And as such, it is evident that it attaches no particular emphasis to the subject. Regardless of this fact, however, that which is important for the purposes of this article and which is also very evident, is that the correlation between thought and existence is a given fact for Parmenides and that it forms the core of his entire philosophical perception.

What we can, therefore, conclude, is that the origin of this fundamental relationship between thought and existence does not in fact begin with the Cartesian "Cogito". This, however, in no way leads, on the other hand, to the conclusion that the Cartesian “Cogito" and Parmenides' Poem Fragment III are saying exactly the same thing. The specific differences between these two conceptions will be examined in greater depth at a later stage. At this point, it is sufficient merely to point out this substantial difference which can be identified from the outset: that, while in Parmenides' Poem Fragment III there is no identity between "vocĩv" and "Ẽ̃val"—as one might erroneously or hastily conclude because of the use of the word " $\alpha$ tó" - but only eternal co-existence, in contrast, in the Cartesian "Cogito", the two concepts are identical. In this second case, Being and thought certainly can be equated, since it is evident that within the general setting into doubt of all things to which Descartes is led, and from which the "Cogito" suddenly springs as the sole founded and irrefutable truth, the only existence which is considered indisputable, and therefore, the only existence which can be considered to exist, is precisely that of thought itself, that of the subject itself who thinks and becomes aware of his own existence. 


\subsection{The Kantian Criticism of the Cartesian "Cogito"}

At this point it must be noted that the Parmenidean conception of uninterrupted co-existence, and not of

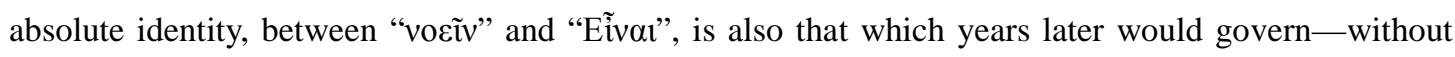
reference to Parmenides, of course - the very criticism which Kant would direct at the Cartesian "Cogito", given that the Kantian criticism undoubtedly leads, not to a refutation of the Cartesian "Cogito", but to a redefinition of it. Kant makes it clear that the "Cogito" is the foundation for the origins of all philosophical contemplation, since the main philosophical problem remains for him also the problem of knowledge- that is to say, of the possibility of accordance, within the realms of truth, of the content of the mental perception we have of things with things themselves, which as such, are outside thought (Note 7). The main philosophical problem which remains for Kant also is the possibility of correlation and accordance between thought and existence. However, this correlation is set on a new basis, since the terms for such a correlation are no longer merely, on the one hand, existence or things in general and, on the other, the psychological experience of subjective consciousness, but on the one hand things themselves, and on the other the transcendental subject or the actual possibility of the existence of a "transcendental philosophy" (Note 8).

The change in the meaning of the subject in Kant lends, in fact, a completely new dimension to the Cartesian indisputable truth "Cogito, ergo sum". In the Cartesian perspective, thought is inner energy with no outward extension, which incarcerates consciousness in itself, self-defining it and shutting it away from the world and from things whose very existence is in doubt. This results, substantially, albeit temporarily, in an identification between thought and Being itself. In contrast, in the Kantian approach, the totality of objects, whose existence is at no point disputed, is that which consciousness, in fulfilling itself, grasps outside and beyond itself, in a transcendental extension, which is in fact that which essentially lays the foundations for consciousness itself, for the subject itself, a priori. That which lays the foundations, a priori, for the very nature of consciousness is its transcendental relation to the object (Note 9).

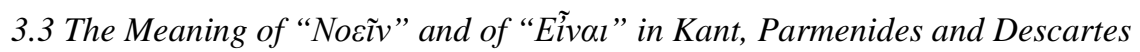

However revolutionary it may appear, both for its own time and for the history of Philosophy in general, the philosophy of the "Cogito" - nwhich is otherwise so self-evident-therefore moves within very narrow confines, given that the correlation between thought and existence, which the "Cogito" asserts, stops at self-awareness, at awareness of the empirical consciousness. The a priori correlation that Kant establishes between subject and object breaks the barrier of self-confinement and connects the subject with the totality of beings. By extension, the correlation between thought and existence assumes in Kant the true dimensions of "vocĩv" and "Eĩval; those dimensions which had originally been determined as such in the Parmenidean fragment III, and which Kant succeeds in encountering. Parmenides' meaning is indeed universal, much broader than Descartes' with regard to "voeiv", and thus much closer to that of Kant, despite the initial contrary view which one might form on the matter 


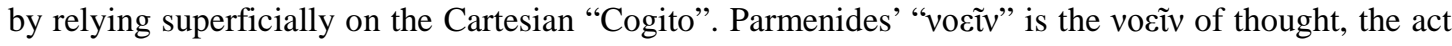

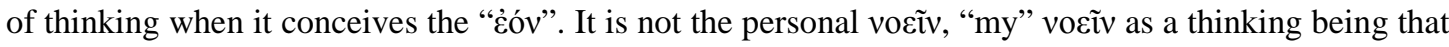
I am—in the exact same way that the Being also in its totality is, as well, for Parmenides, not only the "I", but the totality of the "żóv", within which thought itself has its own place. Besides, in the Parmenidean view it could never be possible to separate the "I" from the rest of the Being or from other beings, for the very simple reason that for Parmenides there are not many beings, but only "one” (Note 10). Even thought itself cannot, therefore, have any place of existence other than within this one Being. With regard to the Cartesian "Cogito", on the other hand, it would not even be correct to speak of the "źóv", or of the "Eĩval". These terms are not representative of the Cartesian conception, given that no reference is ever made to them. Reference is made only to "I am", to individual existence, to "I". Descartes asks “what am I then?”, in order to answer: “a thing which thinks” (Note 11).

Regardless of the degree of approach, or of the convergences and divergences between the philosophers on this fundamental matter of the relation between thought and existence, one thing is certain: that this matter does not constitute a revolutionary invention of Descartes, nor does its historical course of philosophical research begin with Descartes. It constitutes one of the most fundamental objects of philosophical research as a whole.

\subsection{The Relation between Thought and Existence in Plato}

For example, the primary and definitive role that this matter continued to play for Plato also, after Parmenides, is well known. For Plato, thought is the nature of the soul, the essence of human existence. The soul exists in order to think. Only when it is in a state of slavery is it prevented in its task and finds it difficult to think (Note 12). The liberated soul, the soul which is released from the confines of the body, is always the thinking soul, the soul which fulfils its true nature- that is to say, that nature which, in Plato's language, the soul possessed pre-empirically (Note 13).

According to Plato, the relation between thought and existence is not, however, limited to this point alone. In Plato, this relation is not merely a relation between the nature or essence of the soul and its own existence, but transcends the soul itself, since the object of the essence of the soul-that is, of thought-is the Being itself in its totality, over and above each isolated or individual soul or thought. The soul, according to Plato, exists in order to think; and when the soul is thinking by itself as such, alone and unimpeded, the object of its thoughts is only the very existence as such of the Ideas themselves. In other words, the soul exists because it thinks, and that which the soul by itself as such thinks about, is that which exists of itself as such and on which depends the existence of all else (Note 14).

That which is also important to note is that in the case of Plato the relation between thought and existence has a strong immediacy. It is a relation which has been from the outset given as such, which is clearly taken as a given thing, and which emerges spontaneously. The immediacy of this relation is as great as that of the "Cogito". There is, however, one basic difference. The immediacy of the "Cogito" 
arises from the existence of doubt regarding the existence of both the body and all other things in general. In contrast, for Plato, the body exists in the same way that all sensible and intelligible things exist. By extension, according to the Platonic view, the relation among soul-thought-idea cannot be fulfilled in the empiric phase of human existence, except through an arduous and continuous effort to lift or release the soul from the bonds of the body and of matter. This immediacy—which implies the direct acquisition itself of knowledge, the direct knowledge of the Ideas from the soul, intuition-is the immediacy which only the free soul can enjoy. It is, therefore, an immediacy which is itself founded on an essential pre-condition, which is not in the least immediate: the pre-condition of the arduous task of the continuous ascent of the soul towards that which exists by itself as such.

In the case of Descartes, there is no such pre-condition, since within the context of general doubt, the body is not taken into account. On this basis therefore, it seems that in the Cartesian view-at least on the surface-a greater emphasis is placed on the immediacy of the relation between thought and existence than that which can be detected in Plato. This immediacy concerns not only the awareness of the relation that exists between thought and existence, but also in general the question of how knowledge is attained. What generally predominates in Descartes is precisely this direct way of attaining knowledge, the intuitive type of knowledge. That which is perceived in his thought clearly and distinctively, and only that, is indeed considered by Descartes as truth-that is to say, as truly existing (Note 15).

\subsection{The Correlation between Parmenides and Kant Concerning Thought and Existence}

Following this brief reference to Plato and to the correlation between Plato and Descartes with regard to the subject matter in which the present article is interested-namely, the relation between thought and existence-let us now return to the correlation which we examined specifically earlier, between Parmenides and Kant. With regard to this correlation, beyond Descartes, between only Parmenides and Kant, it is important to note also how enlightening is the introductory presentation of Parmenides' Poem by Jean Beaufret (Note 16). In this presentation, Beaufret relies heavily on Heideggerian phenomenology and in general on the interpretation itself which Heidegger gives to the Poem by Parmenides.

In his work Was heisst Denken?, Heidegger notes that, contrary to the usual interpretation, the

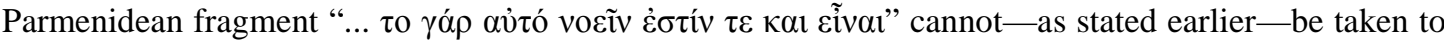

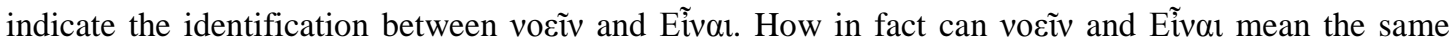
thing? —asks Heidegger. They are in fact different from one another. What is happening-he explains_-and what Parmenides meant to say, is simply that within this difference, they belong to each other, they are inter-dependent. Eĩval is that which offers to vosiv its content, while at the same time vocĩv belongs to Eĩval, lies within Eĩval, precisely as that which owes its existence to Eĩval (Note 17) .Without a doubt, this, besides, is what is demonstrated by verse 34 of fragment VIII (Note 18). Heidegger further stresses that it is the true meaning of the above mentioned fragments of Parmenides' 
Poem which determines the fundamental theme of reference of the whole of western European thought, since the history of this thought, even in cases in which there is no clear reference to Parmenides' thinking, is in fact no more than a chain of diverse ways of formulating this same theme (Note 19) - the most important of which is that which, regardless of the particularities it presents as an entirely different metaphysical theory, is proposed by Kant. The common element of approach which, aside from the differences, enables Kant to meet Parmenides is precisely that inter-dependence which they both see as governing the relation between "vocĩv" and "Eĩval".

What is especially noteworthy and should be mentioned at this point with regard to this meeting between Kant and Parmenides, is also this very fact that the meeting of these two philosophers takes place beyond Descartes. In other words, while that which might externally appear to be so and which one might expect, would be that this meeting does not concern Kant and Parmenides, but rather Descartes and Parmenides, given that the philosophy of the "Cogito" is certainly the philosophy of the most direct way of linking existence with thought, the spirit of Descartes is quite different from that of Parmenides.

3.6 The Conceptual Differences between the Cartesian "Cogito" and Parmenides' Poem Fragment III

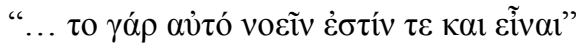

"Cogito, ergo sum"

What is actually the true relation between these two statements? Would it be correct to conclude, or even to assume that the Cartesian "Cogito" is at least one of the diverse ways, to which Heidegger refers generally, by which the words of Parmenides were reformulated in the history of Philosophy? What can be said with certainty is that the Cartesian "Cogito" refers to the specific fragment from Parmenides. What is equally certain though, is that in fact the Cartesian "Cogito" has no substantive relation with this fragment.

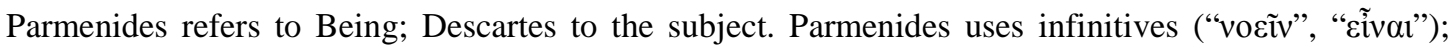
Descartes uses verbs in the first person (“cogito", “sum”). Parmenides uses an assured affirmative sentence, the aim of which is to make a clear statement and to stress a certainty. Descartes uses a sentence in which the terms succeed one another in the form of a conclusion. His sentence is of a deductive character. Its aim is to allow a conclusion to be reached, regardless of the fact that this conclusion happens at the same time to appear to be tautological and to constitute a truth in itself: indeed, the first indisputable truth, for Descartes, and the only one capable of standing up to an utter

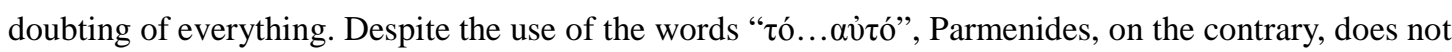
crush the independence of "vocĩv" and "Eĩval", within their inter-dependence. That which Parmenides wishes exactly to emphasize is that, on the one hand, this inter-dependence exists, and on the other, that it is precisely this inter-dependence which at the same time determines the separate and particular

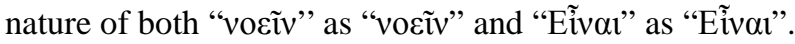

It is precisely this independence within inter-dependence in Parmenides' statement that Heidegger 


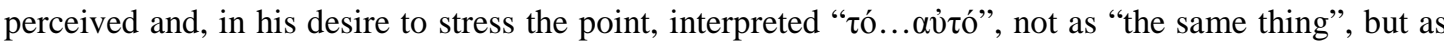
"that which inter-belongs" (Note 20). In other words, Parmenides' sentence, as an affirmative sentence the aim of which is to make a statement, states precisely what it wishes to state concerning both "voeiv" and "Eĩval", maintaining the independence of both terms within their inter-dependence. In contrast, Descartes' use of a deductive sentence, enables us to draw a conclusion only with regard to the subject, while not enabling us to draw any separate inference regarding thought. Thought is crushed since it becomes one with the subject; or better yet, through the crushing of thought, the only thing which is defined is the subject, which is self-defined as a thinking being.

We can therefore infer that, for Descartes, there is no distinction between thought and existence-apart from the fact that thought, as he himself says, is "the essence or the nature" which fulfils existence (Note 21) due to the fact that the two phenomena, both thought and existence, converge in the subject, which to them is not a third term, but one and the same. Indeed, at no time in the Cartesian theory of the "Cogito", is there any mention of existence in general, or of Being as Being in general, but precisely only of the specific subject, of "my ego" and "my" thought. Particularly regarding thought, it should also be stressed here that not only is this not put forward in Descartes in the general sense of the word, but it does not even exclusively mean the mental functions of the mind by which we are in a position to be led to knowledge, as this was understood by both Parmenides and Plato. The act of thinking—as Descartes makes clear—does not embrace solely and exclusively the function of the mind, but also anything which can be characterized "inside me" as sensation (Note 22).

Consequently, neither the concept of "vocĩv" nor that of "Eĩval", nor of course the correlation between these two concepts, as Parmenides understands them, have anything to do with the Cartesian "Cogito". The greatest difference between these two conceptions lies in the fact that, while thought, in the first case, cannot be perceived outside its relation with Being, in the second, it has nothing to do with Being, since it is related only to the subject, through which it reaches self-fulfillment.

Indeed, in the case of Descartes, Being as Being, as a totality, does not exist. Nothing can have anything to do with it—and not even thought itself of course-since it does not exist as such. Only the subject exists. Not even "the subjects". The plural is not appropriate, since Descartes sets in doubt the existence not only of all objects-phenomena, but also the existence of any existence in general, other than that of himself as a thinking subject. For him, Being as a whole is only his own subject. (Note 23) On the other hand, of course, it is a fact that the above view lasted for only a short time. Soon afterwards, Descartes' faith in the existence of all other things, both sensible and intelligible, was restored. It is well known that the doubting of everything outside himself, even of his own body, was merely a method, the aim of which was precisely the regaining of this faith, but this time, on new foundations, on an unshakeable basis, on indisputable truths, which would thus transform faith from a mere belief, based on generally acknowledged facts or prejudices in accordance with the spirit of the Medieval past, into a faith founded in science. It is also a fact that the "Cogito", the first (Note 24) 
indisputable truth—despite the fact that it was initially conceived directly as a necessarily immediate reality-later took its own place in the chain of thoughts which arises from the idea of the existence of God (Note 25), on which this first truth could precisely lay its now established possibility. It is in fact this proven existence of God which, at the final stage of the Cartesian theory, lays indeed the foundations both for the "Cogito" itself and for the truth of all other existence and knowledge-generally enabling Descartes to make Physics a science founded on Metaphysics. Certainly that is how things are and certainly the isolated phrase "Cogito, ergo sum" does not constitute Descartes' entire philosophy. Nonetheless, this fact changes nothing concerning the subject matter of this paper: that is to say, how Descartes sees the relation between thought and Being. Despite the eventual restoration of faith and its foundation in innate, indisputable truths, the fact is that at the crucial moment of the definition of thought, thought is not defined in relation to Being as Being, but in relation to "ego", to the individual consciousness, the specific subject. The fact that this definition itself is possible and achievable first, first in the series, before any other discovery or finding of truth, demonstrates precisely that, for Descartes, thought requires nothing apart from its own self in order to exist, to be that which it is-except of course from the subject which possesses it and from which it is essentially indistinguishable. And this ultimately is the deeper meaning of the Cartesian doubting. However short-lived this doubting may be and however it may be used only as a means, as a method which leads us eventually to established knowledge, even to the knowledge of the very existence of God, its great importance lies mainly in the fact that it demonstrates or underlines the possibility of the "Cogito" to escape from it; or, to put it differently, that it underlines the possibility of thought to exist and fulfill itself, its essence, by itself. Its great importance lies in the fact that it shows clearly that the essence of thought is not its relation to Being, or, even more simply, the very thought of Being, but on the contrary, precisely its own inner self-reliant ability to think innate ideas and truths. This very perception of thought as capable of thinking by itself-that is, with no reference to Being - to anything outside itself, but wholly from an inner self-reliant ability, is a perception which leads Descartes to a different world, a world clearly beyond that of antiquity.

In other words, however intense the relation between thought and existence may appear in the Cartesian "Cogito" - a relation which is not merely familiar, but fundamental to Parmenidean and Platonic philosophy and to the ancient Greek philosophical spirit in general-Descartes in fact has no connection to this spirit, and his philosophy defines the beginning of a new age in which, in the broad

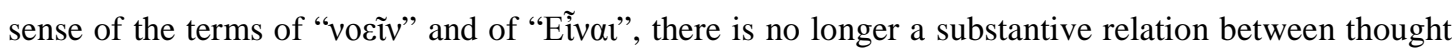
and existence. The only relation which remains a relation in Descartes is that very narrow one between thought and the subject which fulfils it.

\subsection{Beyond Descartes: Kant, Hegel, Heidegger}

Consequently, if Descartes did bring about a revolution, it was not in the discovery of the direct, absolute relation between thought and Being —as it could on a superficial level be understood—but 
actually in the radical withdrawal of thought from Being. Out of this withdrawal springs the subject, which takes the place of Being in an entirely new relation which has no element of comparison with the earlier one. With Descartes, the spirit of the ancient philosophy is abandoned precisely because the

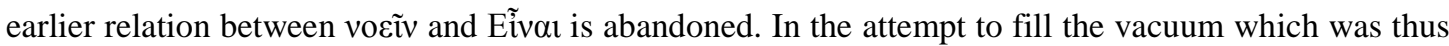
created, various new ways were later devised-noteworthy examples of which are the philosophical theories of Kant and Hegel (Note 26).

The most powerful of all the new methods is, in our view, that proposed by Heidegger-primarily because Heidegger was the first to revert to the ancient vocabulary, which speaks again precisely of "Eĩval" and "vocĩv". Indeed, for Heidegger, that which defines thought is the fact that thought is always the thought of the "Being" of the beings. Beings—although not identical to "Being" itself—do not exist separately from it, which is concealed within them. In this way, the essence of thought does not lie in the discovery of the "Being" of beings beyond beings, but in uncovering, revealing the "Being" concealed within them. The task of thought is to grasp the "Being" which is revealed. The nature of the task of thought is purely phenomenological and no longer metaphysical. Nonetheless, whether it is metaphysical as ancient philosophical thought—and, more precisely, as Plato and Aristotle—conceived it, or phenomenological as Heidegger conceived it, what is important is that in both cases-as also of course in the case of Parmenides-thought cannot be conceived independently of Being. That which in all these cases determines both thought and Being itself is the relation between them. Being is always the Being of the beings and thought exists only as thought of the Being of the beings. (Note 27) Of course, the question of whether the thought of the Being of the beings manages to express faithfully through words that which it conceives, so that what is spoken is precisely what is thought of, and whether that which succeeds in entering the realms of thought is not then lost again in the realms of what is said, is another matter which remains-as Heidegger put it-a question. (Note 28) It is a question which of course had been as such posed much earlier; suffice it to think what was for Plato the meaning of language and how important was for him the possibility of the articulation of correct speech (speech with knowledge and not without knowledge (Note 29)), and how difficult at the same time he considered such a possibility to be (Note 30).

Despite the similarities among the ancient ontological view and the Heideggerian, regarding the concepts of Being and thought, between the ancient philosophers and Heidegger there have been philosophers with entirely different views, such as Descartes, who-while appearing to maintain and indeed emphasize the relation between Being and thought—in fact abandoned this essential relation, with the result of the sudden discovery, or emergence, through this abandonment, of the thinking "ego", the subject, the individual consciousness. 
3.8 The Emergence of the Individual Consciousness and the New Theories Which Sprang from the Cartesian Perception of the "Cogito"

Of course, at this point the question arises of whether the Cartesian "Cogito" refers to consciousness in the real sense indeed of the individual consciousness and uniqueness of the individual, or, on the contrary, to the impersonal thought which as such retains the character of universality. What is in fact being raised here is a classic question with which commentators of Cartesian rationalism have always concerned themselves. Some of these important commentators, such as Hamelin and Brunschvicg (Note 31), consider that the "Cogito" does indeed constitute the support basis for the thesis of an impersonal thought in which all participate on the universal level, and through which all acquire the capability to conceive the truth—precisely because this universal thought, common to all, is the holder of innate ideas.

Despite this fact, however- that is to say, despite the fact that thought, as the holder of innate ideas, has the characteristics of universality - it is, in our view, clear at the same time that it is not, nevertheless, an impersonal thought which is discovered through the "Cogito", but on the contrary and primarily that thought which appears as inseparable from a specific and empirical subject.

As pointed out by Geneviève Lewis in her work L' individualité selon Descartes, in his analysis, Descartes never separated thought from an "ego" to which it belongs, given that the "Cogito" is expressed in the first person-a first person doubly stressed by the use of the word "ego" itself: "Ego cogito, ergo sum”. (Note 32) Besides, when Descartes describes "what is a thing which thinks", he points out that it is "a thing which doubts, which understands, which affirms, which denies, which wants, which does not want, which also imagines and which feels”. (Note 33) It is, therefore, a fact that the "Cogito" is from the beginning set on an empirical level, on the level of the psychological experience of a specific subject, not in the least impersonal and not in the least unconnected with the moment in time or with time in general. The definition of thought is clearly outlined in correlation with a subject both temporal and empirical: "It is of itself so evident that it is I who doubts, who hears and who desires, that it is not necessary here to add anything further in explanation”-Descartes states clearly and indisputably. (Note 34) In consequence, that which the Cartesian "Cogito" allows us to conclude, is that, while the characteristics as such of thought, as thought, are universal, thought itself is not impersonal. Thought is personal: it is "my" thought. It is always the thought of a specific "ego", the thought of a particular individual.

This sudden emergence of the individual consciousness was to form the basis for the later creation of new philosophical theories of common origin, as regards reference to and reliance on what we call "the subject”. Without the existence of a direct, or even of any, relation to or continuation from Descartes' philosophy itself, all those philosophies which sprang from the Cartesian perception of the "Cogito" - in addition to the separate, dissimilar elements which distinguish each one of them-have one thing in common: they no longer deal with Being, but only with human beings, individual 
existences, subjects. Apart from the clearly existential theories, which are more recent, it can be considered that such varied forms of philosophical theory, whose sole common element is the reference to the subject, even include the thinking of philosophers such as Spinoza (Note 35) and Leibniz (Note 36).

\subsection{From the Cartesian "Cogito" to Structuralism}

With the Cartesian revolution of the "Cogito", the epicentre of philosophical thought shifted from Being to the subject. Later it would shift even further: from the subject to the "structure", or rather, the "structures". The "structures" are always many in number, since they are those which are found beneath every kind of action or manifestation, whether individual or social. In Structuralism, the theory of "structures", the subject is lost, since nothing which belongs to it, even its very language (Note 37) and all its various relationships (Note 38) and its ideology (Note 39), is in fact its own. All that exists or occurs, whether it concerns the subject directly or indirectly, is merely a result, a product: the product of certain structures which lie in the background and which by their existence constitute the determining cause of any possible appearance, or development, or disappearance of particular conditions and circumstances.

Of course at this point it must be made clear that this particular reference to Structuralism in no way aims at correlating this theory with that of Descartes. No such essential or direct correlation can be made.

\section{Final Concluding Remarks}

What can be achieved, however, vis a vis the history of Philosophy as a whole—and this is put forward as a final point of analysis and in the form of a general conclusion for this paper-is some correlation of direction, regarding this matter. In other words, since it is to Descartes that we owe the first essential discovery of the subject, it is to him also that we can attribute the gradual origins of the progressive shifting in the centre of weight, which would eventually lead to the elimination itself of the subject. The most important fact of all is that between these two limits, of discovery and elimination, there have been attempts to recover and meet pre-Cartesian philosophical thought, attempts to encounter Being beyond the subject.

\section{References}

Althusser, L. (1965). Pour Marx. Maspéro.

Corte, M. de. (1938). Anthropologie platonicienne et anthropologie aristotélicienne. Etudes carmélitaines.

Descartes, R. (1953). Les principes de la philosophie—Discours de la méthode-Méditations. Euvres et Lettres-Bibliothèque de la Pléiade, Gallimard.

Foucault, M. (1966). Les mots et les choses. Gallimard. 
Hegel, G. W. F. (1970). Leçons sur l' histoire de la philosophie (J. Gibelin, Gallimard, Trans.).

Heidegger, M. (1992). Qu’ appelle -t- on penser? (Aloys Becker \& Gérard Granel, Trans.).

Jakobson, R. (1963). Essais de linguistique générale.

Kant, I. (1998). Critique of Pure Reason (P. Guyer \& A. W. Wood, Trans.).

Kant, I. (1979). Critique of Pure Reason (A. Yiannaras, Trans.).

Leibniz, G. W. (1986). Discours de Métaphysique. Presentation by Henri Lestienne, Vrin, Paris.

Lévi-Strauss, C. (1967). Les structures élémentaires de la parenté. Mouton.

Lévi-Strauss, C. (1958). Anthropologie structurale. Plon.

Lewis, G. (1950). L' individualité selon Descartes. Vrin, Paris.

Parmenides. (1912). Poem, Kranz W. and Diels H., (1952 ed.). [Re-publication of Diels’ work Die Fragmente der Vorsokratiker].

Parmenides. (1984). Poem (Parménide, Le Poème), Presentation by Jean Beaufret, PUF, 2nd ed.

Saussure, F. De. (1986). Cours de linguistique générale. Payot.

Spinoza, B. (1986). Ethics (A. Boyle, Trans.).

\section{Notes}

Note 1. "I think, therefore I am”: R. Descartes, Les principes de la philosophie, part 1, par.7; Discours de la méthode, part 4, pp. 147, 148; Méditations, II, pp. 275, 277 Euvres et Lettres—Bibliothèque de la Pléiade, Gallimard, 1953.

Note 2. I. Kant, Critique of Pure Reason, Transcendental Dialectics, book II, chapter 1, English translation by P. Guyer and A. W. Wood, Cambridge University Press, 1998, pp. 411-458.

Note 3. R. Descartes, Discours de la méthode, parts 3 and 4.

Note 4. Parmenides, Poem, fragment III [according to the order of presentation of the fragments adopted by Walther Kranz on re-publication (1952) of Diels' work Die Fragmente der Vorsokratiker (1912)].

Note 5. Ibid., fragments VI and VII.

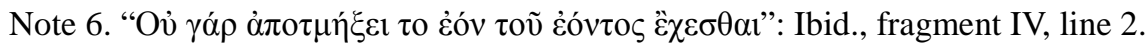

Note 7. This concerns the problem of the possibility of existence of a priori knowledge: I. Kant, Critique of Pure Reason, Prologue to the second edition, Greek translation by A. Yiannaras, Papazisis Publications, 1979, BXVII-BXXI, pp. 45-48.

Note 8. Ibid., Introduction, VII, A 12, p. 97.

Note 9. This Kantian conception of the consciousness as such can clearly also be considered as corresponding with the Husserlian conception of the intended direction of consciousness towards objects.

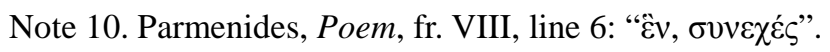

Note 11. “Mais qu' est-ce donc que je suis? Une chose qui pense”: R. Descartes, Méditations, II, p. 278. 
Note 12. Plato, Phaedo, 66b-67.

Note 13. Ibid, 75d-76a -Plato, Phaedrus, 249c-e.

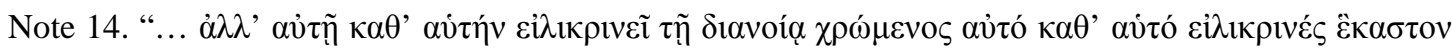

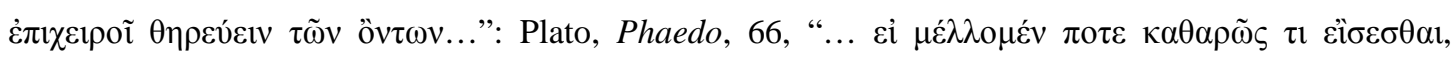

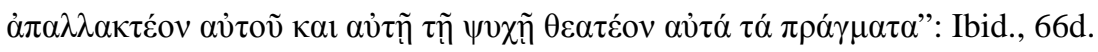

Note 15. R. Descartes, Méditations, IV, p. 309, Discours de la méthode, part 4, p. 151.

Note 16. Parménide, Le Poème, in a presentation by Jean Beaufret, PUF, 2nd edition, 1984.

Note 17. M. Heidegger, Qu' appelle -t- on penser?, French translation by Aloys Becker and Gérard Granel, Quadrige/PUF, 1992 edition, pp. 222-223.

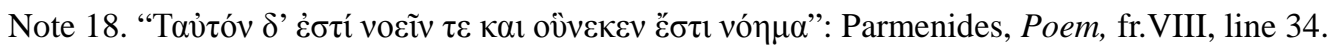

Note 19. M. Heidegger, Qu' appelle -t- on penser?, French translation by Aloys Becker and Gérard Granel, Quadrige/PUF, 1992 edition, p. 224.

Note 20. “ce qui s’ entre-appartient”: M. Heidegger, Qu’ appelle -t- on penser? French translation by Aloys Becker and Gérard Granel, Quadrige/PUF, 1992 edition, p. 223.

Note 21. “Je connus de là que j' étais une substance dont toute l' essence ou la nature n' est que de penser”: R. Descartes, Discours de la méthode, part 4, p.148.

Note 22. “... et c’ est proprement ce qui en moi s’ appelle sentir, et cela, pris ainsi précisément, n’ est rien d' autre chose que penser”: R. Descartes, Méditations, II, p. 279.

Note 23. “... encore que hors de moi il n’ y eut point d' autres hommes dans le monde...”: R. Descartes, Méditations, III, p. 292. The utter doubting of everything is described characteristically at the beginning of Méditation II, pp. 274-275.

Note 24. “... le premier principe de la philosophie que je cherchais”: R. Descartes, Discours de la méthode, part 4, p. 148.

Note 25. R. Descartes, Méditations, III, p. 294.

Note 26. Extensive reference is already being made to Kant in this paper. As far as Hegel is concerned,

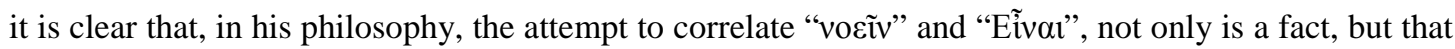
this fact leads also eventually to the equation between these two concepts- that is to say, to this equation which, although at first sight may appear already to have existed in the thinking of Parmenides, the latter had not in fact adopted it. Hegel, on the contrary, appears indeed to adopt it, since his entire philosophical system precisely identifies history — that which is real—with the Idea itself. Thought is identified with existence, since the whole of existence, the whole of historical reality is considered as an external manifestation of the Idea, which is fulfilled gradually and dialectically in the evolution of history. At no stage of its historically evolutionary completion can the Idea be separated from historical reality itself. Each historical moment is a manifestation of the Idea, and therefore an identification of the real with the intelligible (G. W. F. Hegel, Leçons sur l' histoire de la philosophie, French translation by J. Gibelin, Gallimard, 1970, vol. I, pp. 119-122). 
Note 27. This Heideggerian perception of the Being, not as the Being as such, but as the Being of the

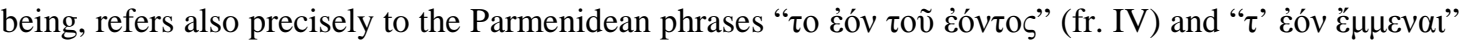
(fr. VI). The definition of thought as the thought of the Being of the being is based on this view of a dual aspect: M. Heidegger, Qu'appelle -t- on penser?, French translation by Aloys Becker and Gérard Granel, Quadrige/PUF, 1992 edition, pp. 210-226.

Note 28. Ibid., p. 226.

Note 29. The utterance of correct speech is considered so important and imperative, that Plato avers that, in order to be guided in speech, man must possess a science capable at all times of indicating to him which of the genera are in agreement and can therefore be joined together in speech and which are

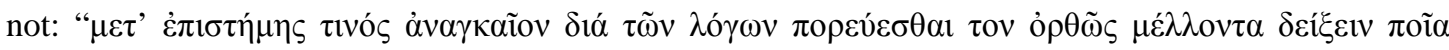

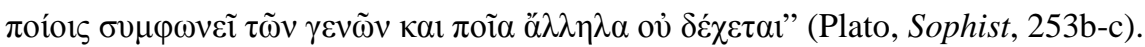

Note 30. This ability belongs solely and exclusively to the philosopher, since only the philosopher possesses the science needed for this purpose, namely dialectics (Ibid., 253d-e).

Note 31. To Hamelin and Brunschvicg, M. de Corte makes special reference in his work “Anthropologie platonicienne et anthropologie aristotelicienne”, Etudes carmélitaines, 1938, pp. 65-66.

Note 32. G. Lewis, L’ individualité selon Descartes, Vrin, Paris, 1950, p. 98.

Note 33. 'Qu' est-ce qu' une chose qui pense? ... une chose qui doute, qui conçoit, qui affirme, qui nie, qui veut, qui ne veut pas, qui imagine aussi, et qui sent” : R. Descartes, Méditations, II, p. 278.

Note 34. “.... il est de soi si évident que c’ est moi qui doute, qui entends, et qui désire, qu’ il n’ est pas ici besoin de rien ajouter pour l' expliquer”: Ibid.

Note 35. According to Spinoza, all men are born without any knowledge of the causes of things, while at the same time possessing a constant desire to move towards that which is useful to them, in order to succeed in maintaining their existence. The reason for their ignorance, the reason for which the soul or thought does not maintain either for itself or for the body any clear and exact knowledge, but only a confused and fragmented knowledge, is because this knowledge is determined wholly by external factors, by the laws of a universal determinism. In this way, the philosophy of Spinoza is the philosophy of human beings, of individuals, of subjects, perceived as a finite and imperfect part of a perfect and infinite totality, by which they are determined and on which they depend at all times, and who- owing precisely to this dependence-are unable to conceive by themselves through reason the totality of causes of which they are the result. All that they are capable of and which characterizes them is the tendency to maintain their existence in duration, without ever knowing either what it is which impels them to maintain it, nor what is precisely the duration or chain of time (B. Spinoza, Ethics, I, App. and II, prop. 29, scol, English translation by A. Boyle, Everyman’s Library, 1986 edition, pp. 30-36 and 61-62).

Note 36. In Leibniz we also encounter a philosophy of the many: the philosophy of monads. Of course monads are not exactly human beings, subjects, given that they are indivisible unities, which as such do 
not appear to provide any space for the body. They do however have characteristics in common with human beings, given that each monad, despite having the same characteristics as all other monads, cannot be identified with any monad other than itself. At the same time, while each monad cannot be separated into parts, is not divisible, inside each monad can be found a replication of the whole world; that same world which is in fact outside all monads, constituting only the space for the totality of monads. In the same way, each human being, through his differentiality and uniqueness, expresses the same phenomena, constitutes in his own particular way a microcosm of the universe, and therefore, accords proportionately with all others. The very possibility of the existence of the universe relies precisely on this proportionately reciprocal concordance of manifestations of the various monads-beings (G. W. Leibniz, Discours de Métaphysique, in a presentation by Henri Lestienne, Vrin, Paris, 1986 edition, 5 IX, 9 XIV).

Note 37. For example, F. de Saussure, Cours de linguistique générale, Payot, 1986 edition; R. Jakobson, Essais de linguistique générale, Ed. de Minuit, 1963.

Note 38. For example, C. Lévi-Strauss, Les structures élémentaires de la parenté, Mouton, 1967-C. Lévi-Strauss, Anthropologie structurale, Plon., 1958.

Note 39. For example, M. Foucault, Les mots et les choses, Gallimard, 1966; L. Althusser, Pour Marx, Maspéro, 1965. 